\title{
In Memoriam: Isabel A. Forsyth 1936-2016
}

\author{
Margaret C. Neville ${ }^{1,2} \cdot$ Malcolm Peaker $^{3}$
}

Received: 9 May 2016 / Accepted: 20 May 2016/Published online: 28 May 2016

(C) Springer Science+Business Media New York 2016

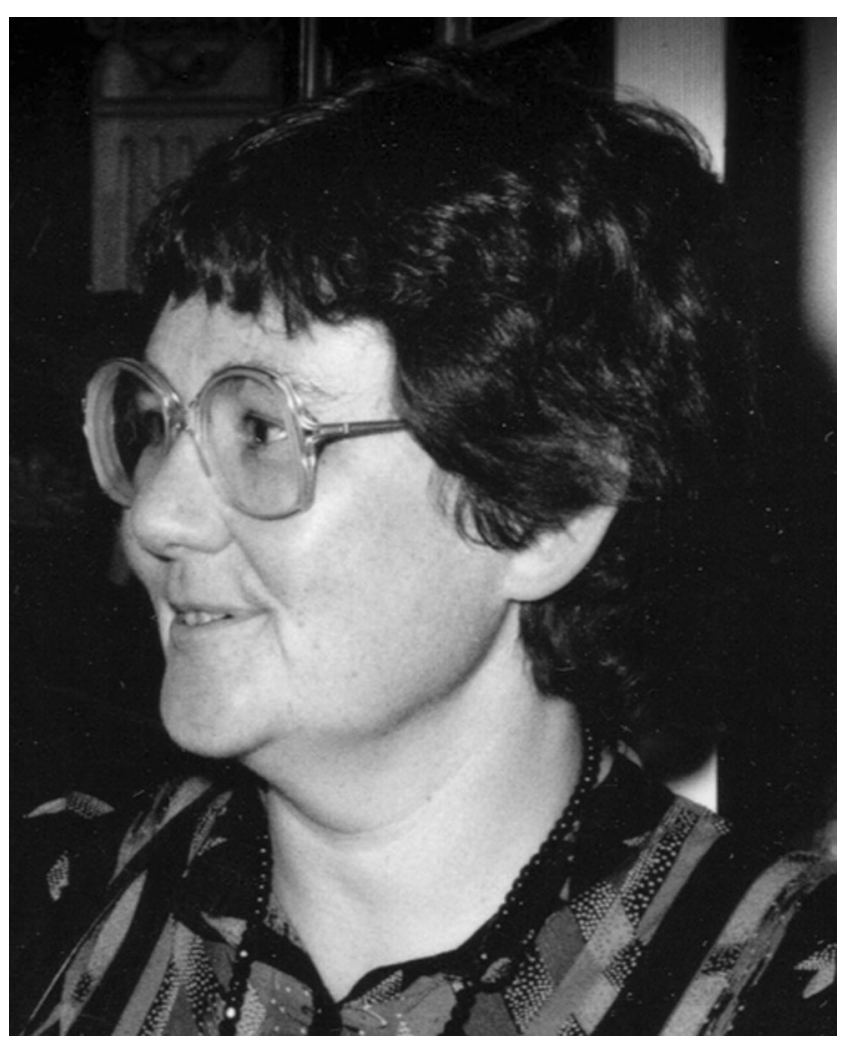

Margaret C. Neville

peggy.neville@ucdenver.edu

1 University of Colorado School Of Medicine, Aurora, CO 80045, USA

2712 Eveningstar Rd, Silverthorne, CO 80498, USA

313 Upper Crofts, Alloway, Ayr KA7 4QX, UK
Isabel Forsyth grew up in Nottingham, England, and attended Somerville College at Oxford University receiving a B.A. in Zoology in 1958 and the Doctor of Philosophy degree from that institution in 1962. Her first published papers were on seasonal breeding cycles in voles with J.R. Clarke [1]. In 1962 she took up a Research Scientist position in S.J. Folley's department at the National Institute for Research in Dairying in Shinfield, Reading, becoming Head of the Physiology Department in 1983. When Shinfield closed in 1985 she became head of Endocrinology and Physiology at the AFRC Institute of Grassland and Environmental Research at Hurley, Maidenhead, a position she held until 1991 when this institution also fell victim to the downsizing of agricultural research in the United Kingdom. Fortunately, the AFRC Institute at Babraham, Cambridge, continued to lead in Agricultural Research at that time and she moved her laboratory there; she was Head of the Reproductive Physiology Laboratory until her retirement in 1996.

Isabel travelled widely. Supported by the Fulbright Commission she worked at the University of California, Berkeley in 1975-6. In 1992 she was a visiting researcher at the University of Western Australia.

The endocrine control of lactation was an important focus of research at Reading where Folley and Alfred T. Cowie had already spent nearly two decades studying the effects of ablation of endocrine organs and the effect of exogenous hormones on lactation in rats, goats and cows. The question was, however, what was the nature of the pituitary hormones that mediated these effects. On arrival at Reading in 1962, Isabel immediately began developing assays for the lactogenic activity of pituitary hormones, using both the pigeon crop sac and organ culture of the mouse mammary gland to differentiate between pituitary growth hormone and prolactin. Within six years she had written 12 papers analyzing the concentration and lactogenic activities of growth hormone and prolactin 
in goats, rats and particularly humans. Working with medical professionals at St. Bartholomew's Hospital in London she found that galactorrhea in humans was associated with increased concentrations of a lactogenic hormone, prolactin, in human plasma [2]. This observation provided strong evidence that prolactin was distinct from growth hormone. In the same year she published a comprehensive review of organ culture techniques and the study of hormone effects on the mammary gland [3] and an article with Ray Dils showing that prolactin stimulated fatty acid synthesis in the rabbit mammary gland in vitro [4]. In 1975 she collaborated with A.T. Cowie on a comprehensive review of the biology of prolactin, pointing out that the hormone has effects both on mammary growth (mammogenic effects) and on milk secretion (galactopoietic and lactogenic effects)[5]. In 1980 the two of them in collaboration with Ian Hart published an enormously influential book, The Hormonal Control of Lactation, [6] a reference work which guided research on the endocrine regulation of mammary growth and milk secretion for decades to come.

In the early 1970's Isabel began working on a lactogenic hormone that appeared during pregnancy in goats, but was not prolactin. This hormone was identified as placental lactogen; its effects could be distinguished from prolactin in goats by use of bromocriptine, an inhibitor of prolactin but not placental lactogen secretion [7]. The findings from this study identified placental lactogen as an effective mammotropic hormone in goats [7]. She continued to work on the properties and localization of this hormone through the remainder of her career, publishing a final review on the topic in 1994 [8]. In addition, her positions at Reading, Hurley and finally Babraham allowed her to collaborate on investigation of a number of hormones and receptors involved in secretory development of the mammary gland including transforming growth factor- $\alpha$ [9], insulin-like and epidermal growth factors [10], and even amphiregulin [11]. She continued to collaborate on publications well after retirement publishing reviews on the molecular evolution of prolactin and growth hormone [12], hormonal control of lactation $[13,14]$ and the functional role of oxytocin [15] well after the turn of this century.

Isabel also had interests outside of science: She was a member of the Royal Shakespeare Society and attended many of their productions. She volunteered for Oxfam in the Saffron Walden book shop one afternoon a week for 15 years and helped raise $£ 200,000$ for the local Anglo Saxon church. She worked for a local art gallery, the Fry gallery, dedicated to the art of East Anglia. Isabel was married to Bill Leeming on October 14, 1967. He says of this nearly 50 years of marriage "Our married life was one of great love and happiness and not a day went by when we didn't find something to laugh about." Isabel will be missed in both the scientific and local communities.

\section{Selected publications of I.A. Forsyth}

1. Clarke JR, Forsyth IA. Seasonal changes in the gonads and accessory reproductive organs of the vole (Microtus Agrestis). Gen Comp Endocrinol. 1964;4:233-42.

2. Forsyth IA, Besser GM, Edwards CR, Francis L, Myres RP. Plasma prolactin activity in inappropriate lactation. Br Med J. 1971;3(5768):225-7.

3. Forsyth IA. Reviews of the progress of dairy science. Section A. Physiology. Organ culture techniques and the study of hormone effects on the mammary gland. J Dairy Res. 1971;38(3):419-44.

4. Forsyth IA, Strong CR, Dils R. Interactions of insulin, corticosterone and prolactin in promoting milk-fat synthesis by mammary explants from pregnant rabbits. Biochem J. 1972;129(4):929-35.

5. Cowie AT, Forsyth IA. Biology of prolactin. Pharmacol Ther [B]. 1975;1(3):437-57.

6. Cowie AT, Forsyth IA, Hart IC. Hormonal control of lactation. Monogr Endocrinol. 1980;15:1-275.

7. Forsyth IA, Byatt JC, Iley S. Hormone concentrations, mammary development and milk yield in goats given long-term bromocriptine treatment in pregnancy. J Endocrinol. 1985;104(1):77-85.

8. Forsyth IA. Comparative aspects of placental lactogens: structure and function. Exp Clin Endocrinol. 1994;102(3):244-51.

9. Moorby CD, Taylor JA, Forsyth IA. Transforming growth factoralpha: receptor binding and action on DNA synthesis in the sheep mammary gland. J Endocrinol. 1995;144:165-71.

10. Forsyth IA. The insulin-like growth factor and epidermal growth factor families in mammary cell growth in ruminants: action and interaction with hormones. J Dairy Sci. 1996;79:1085-96.

11. Forsyth IA, Taylor JA, Keable S, Turvey A, Lennard S. Expression of amphiregulin in the sheep mammary gland. Mol Cell Endocrinol. 1997;126(1):41-8.

12. Forsyth IA, Wallis M. Growth hormone and prolactin-molecular and functional evolution. J Mammary Gland Biol Neoplasia. 2002;7(3):291-312.

13. Neville MC, McFadden TB, Forsyth I. Hormonal regulation of mammary differentiation and milk secretion. J Mammary Gland Biol Neoplasia. 2002;7(1):49-66.

14. Forsyth IA, Neville MC. Introduction: hormonal regulation of mammary development and milk protein gene expression at the whole animal and molecular levels. J Mammary Gland Biol Neoplasia. 2009;14(3):317-9.

15. Forsyth IA, Neville MC. Introduction: the myoepithelial cell and milk letdown; entrance to the multifunctional role of oxytocin. J Mammary Gland Biol Neoplasia. 2009;14(3):221-2. doi:10.1007/ s10911-009-9147-3. 